produce brilliant phosphorescence, and sometimes fusion, of solid matter.

But Tesla's main purpose was the transmission of power and messages across space. In 1892 and 1893 he developed his scheme. High-frequency power was to be led to a large antenna consisting of an elevated metal area connected by a vertical wire to a large metal plate buried in the earth. The receiving antenna was to be equal in every respect. The figure in the Journal of the Franklin Institute shows the source of oscillations connected into the vertical wire near the earth at the sending station, and the receiving apparatus in the corresponding place at the receiving station. He did not patent the antenna. Tesla states his belief that the electrical oscillations will be propagated along the surface of the earth and that they may be assisted by an upper conducting layer of the atmosphere-this is eight years before Heaviside and Kennelly. Tesla had thus supplied, two years before wireless began its commercial career, all the elements of both spark and continuous wave sending stations. For the receiving station the Lodge or Branly coherer was already available for spark telegraphy, but Tesla concentrated on continuous waves because he was more interested in the transmission of power than in the transmission of messages. After building one or two small stations, he started in 1897, at his own expense, a station of 200 kilowatts in Colorado. From this point in 1899 he transmitted power enough to light a lamp at $30 \mathrm{~km}$. For the reception of continuous wave signals he invented the interrupter device known as a ticker, which was employed by others for the next dozen years, and from the Colorado station received signals at a distance of $1,000 \mathrm{~km}$. Later, his form of antenna, his rotating discharger, and his tuned transformer were used successfully by many others at spark stations in every country.

Space limits this survey to a few of the new things which Tesla's creative imagination and constructive genius gave to the world. His other inventions include pyro-magnetic generators, thermo-magnetic motors, unipolar dynamos, meters, lamps, mechanical vibrators of huge power and a variety of instruments. Some seven hundred patents stand in his name, mostly taken out before he was fifty years of age. Apparently his method of work was to state a problem, devise solutions, build machines and file a patent specification or, possibly, read a paper to a technical society. Then he would start on a new problem. It happened that one of his subjects, high-frequency discharge, made a brilliant display, and he was persuaded to lecture upon it several times. The demonstrations were perfect and very showy; consequently sober folk concluded that Tesla was somewhat of a showman. This is quite wrong. Throughout his long life of eighty-five years, Tesla seldom directed attention to his own successes, never wrote up again his old work, and rarely claimed priority though continually pirated. Such reserve is especially striking in a mind so rich in creative thought, so competent in practical achievement.

\section{W. H. Eccles.}

\section{Dr. A. L. Lowell}

OF the two late presidents of Harvard, Eliot and Lowell, it was said that Eliot found Harvard a college and built upon it a university, while Lowell found a university and unearthed its college. Eliot developed great post-graduate schools, from medicine to business administration; but his free elective system for undergraduates left the college almost spineless. It was for his successor to revalue the meaning of a B.A. degree, and he did.

The chief monument of Lowell will be his scheme of concentration (reading one main subject) and his general examination (final schools). Anglophile in nothing so much as in education, he had always approved of this method, nearly identical with that of Oxford and Cambridge, but had to watch the previous regime spare the rod and spoil the undergraduate. In the last decade of Eliot's reign, most pupils used to scoff at honours; in the last decade of Lowell's, the tendency was to scoff at those unequal to reading for them.

The second great change under Lowell was likewise of British pattern. He broke up an unwieldy university into colleges, again like Oxford and Cambridge. Long a cherished plan of his, he lacked funds for it, until one day about fifteen years ago a stranger ealled at the President's office. Lowell, in the midst of a busy morning, almost did not see the caller-a certain Mr. Harkness. "If," said the stranger, "you suddenly had a lot of money given you-let us say millions-for the university, what would you like to do with it ?" Lowell actually produced a set of blue-prints from a drawer. "Build separate colleges," said he promptly. "Exactly my idea," responded Harkness." "Yale, where I come from, has declined such a gift. Will you take it, and how much do you need ?" The result was the seven 'Harvard Houses' -built either entirely new or to include conversion of several hostels already in use-at the cost of $3 \frac{1}{2}$ millions sterling. (Yale then changed its mind, whereupon Harkness cheerfully donated enough more to Yale for a similar project. It was Harkness funds, of course, which also came later to Great Britain for the Commonwealth Fellowships and for the Pilgrim Trust.)

The third milestone in the presidency of Lowell was once more inspired by the example of England. $\mathrm{He}$ founded in Harvard the Society of Fellows, an adaptation of All Souls, Oxford. Under this foundation-the funds said to have been given by Lowell, himself a wealthy man-a committee of senior fellows, members of staff in Harvard, elect each year eight junior fellows, graduates of any American university of standing, for postgraduate research. These fellowships yield enough to cover all expenses of the holder, and are renewable (from three to six years) until his specific problem of research is completed. He has the utmost freedom, being not required to work for a degree. Junior fellows live in the various 'Houses', and in time may be offered appointments to the staff.

As the most important personality in American education in his time, Lowell exerted a national influence. So appreciative of his leadership were benefactors, whether old Harvard men or not, that during his own tenure of office-twenty-four yearshe saw the endowment of his University tripled; when he retired in 1933 it stood at some thirty millions sterling. A dozen books which Lowell wrote will ensure him remembrance as an authority on government-government in America, in Great Britain, and on the Continent; but his annual reports, as president, to the Overseers of Harvard, are essays in the advance of education, not at Harvard only, but also throughout America.

Lowell died on January 6 at the age of eighty-six. WILLARd CONNELy. 